\title{
The Association of TSHR Gene rs2268458 Polymorphism with Hypothyroidism in Females of Babylon Province- Iraq
}

\author{
Batool Ibrahim Hussain ${ }^{\text {a }}$ \\ Maysaa Adil Hadi ${ }^{b}$ \\ Hussein Jasim AL-Harbi \\ a University of Babylon /College of Nursing,Babel, Iraq. \\ b,c University of Babylon /College of Science,Babel, Iraq. \\ Batoolibrahim1977@gmail.com mys_adil@yahoo.com husseinjasim1967@gmail.com
}

Submission date:- 22/1/2018 Acceptance date:- 29/1/2018 Publication date:- 30/7/2018

Keywords: TSHR gene, rs2268458 polymorphism, hypothyroidism, Iraq.

\begin{abstract}
The Aim: To evaluate the association of TSHR gene polymorphism rs2268458 with some Physio-biochemical parameters among hypothyroidism women.

Methods: This study included 51 hypothyroidism women and 43 healthy women as a control group. Some Physiobiochemical (body mass index (BMI), cytochrome 450 1A1 (CYP1A1), calcium, and phosphorus) and hormonal assay (Osteopontin (OPN), thyroid stimulating hormone (TSH), fT3, fT4 and Calcitonin (CT)) assay were performed. Genotyping of rs-2268458 of TSHR gene was carried out using the polymerase chain reaction-based restriction fragment length polymorphism (PCR-RFLP) technique.

Results: TSHR rs2268458 was associated with hypothyroidism in Iraqi women and allele $\mathrm{C}$ can be a risk factor for disease by $\mathrm{OR}=4.393, \mathrm{CI}=1.42-13.53$ where $\mathrm{TC}$ and $\mathrm{CC}$ genotypes were associated with high BMI, while TC genotype was associated with high calcitonin and CYP1A1 levels.

Conclusion: The TSHR rs2268458 polymorphism was associated with hypothyroidism in Iraqi women and allele C can be a risk factor for some Physio-biochemical and hormonal disorder in hypothyroidism women.
\end{abstract}

\section{1- Introduction}

Hypothyroidism is an endocrine disorder defined as a deficiency in thyroid hormone production [1]. It is linked with a variety of signs as fatigue, bradycardia, depression, obesity, and hyperlipidemia [1],[2]. Thyroid hormones act a crucial physiological action on the metabolism and individual development [3]. The thyroid hormone receptor act as a transcription factors ligand to block or initiate the expression of a target gene after binding to thyroid hormone response elements (TRE) in promoter regions of the target gene[4]. When thyroid hormone is absent, thyroid receptors inhibit linked genes expression [5]. Thyrotropin or thyroid stimulating hormone (TSH) is the mainly Sensitive and valuable test for thyroid function [1]. TSH regulates the secretion of the thyroid gland and growth through binding to its receptors (TSHR) [6]. Genetic variants in the TSHR gene was described to be associated with the risk of thyroid diseases. [7]

The previous genome-wide association studies showed that chromosome 14 has a high level of association with hypothyroidism disease and the highest region are in $35 \mathrm{Mbp}$, region $95 \mathrm{Mbp}$ and the highest region in the site of $93 \mathrm{Mbp}$ is near to the polymorphism (rs 2268458) which locate at region 81Mbp as show in the figure (1). 


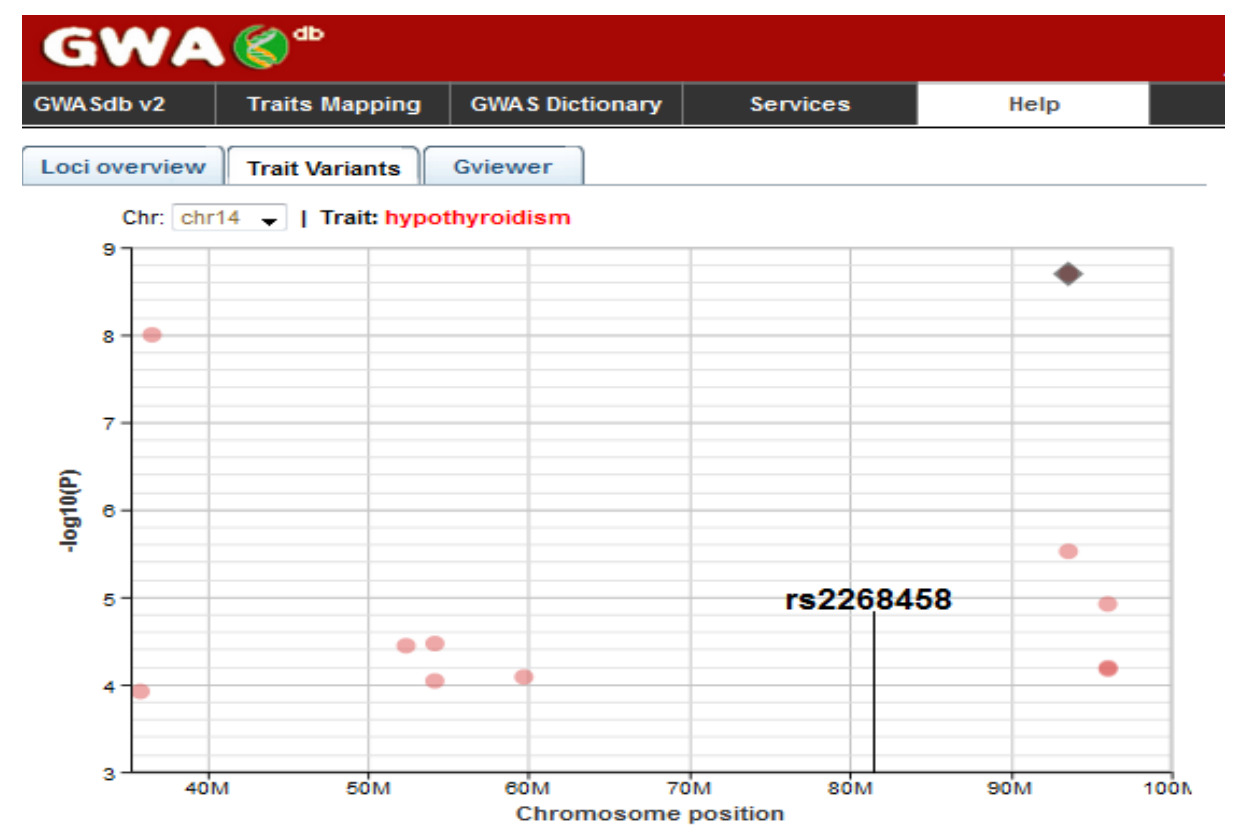

Figure (1): The association of chromosome 14 with hypothyroidism according to genome-wide association studies plotted by GWASdb.

Polymorphism in TSHR rs2268458 which located in intron 1 of the TSHR gene had been confirmed its association with Graves' Disease (GD) in Caucasians[8]. So this study planned to evaluate the association of TSHR gene polymorphism rs2268458 with the risk and the prognosis of hypothyroidism in Iraqi women (Babylon Province).

\section{Subjects and Methods}

The samples were collected from Mrjan teaching hospital/ Babylon province/ Iraq and patients were diagnosed by a physician which included 51 hypothyroidism women and 43 healthy women. Blood was withdrawn $(5 \mathrm{ml})$ and dispersed into 2 parts, the first part in the anticoagulant-free plain tube for biochemical assays and the second part $(2 \mathrm{ml})$ into an EDTA tube for DNA extraction. Centrifugation of blood had been made after 30 minutes of sampling and storage of serum was at $-20^{\circ} \mathrm{C}$ until the biochemical assays (CYP1A1, calcium, and phosphorus) and hormonal assays (OPN, TSH, fT3, fT4, and CT) were performed. All routine study parameters were estimated in serum samples of these 51 hypothyroidism women and healthy control women using standard techniques. Levels of TSH (Bio-merieuxSA/ France), fT3, fT4, OPN, CYP1A1, and calcitonin (Elabscience) were evaluated by Enzyme-Linked-Immuno-Sorbent Assay (EL-ISA).

Calcium (Randox/ United Kingdom) and phosphorus (Spinreact, S.A.U./SPAIN) levels were done by a colorimetric method and the absorbance of color was read by spectrophotometer at $570 \mathrm{~nm}$ for calcium and 710 $\mathrm{nm}$ for phosphorus. The formula BMI= weight $(\mathrm{kg}) /$ height $^{2}(\mathrm{~m})^{2}$ was used for estimation of body mass index (BMI).

\section{Exclusion criteria}

There are several pathological, normal physiological conditions and daily habit can interfere with hypothyroidism case were excluded from this study such as heart disease, hypertension, diabetes mellitus, pregnancy, and smokers.

\section{DNA extraction}

Genomic DNA from white blood cells (WBCs) for both hypothyroidism patients and control group were extracted by using DNA extraction kit (Favorgen/Taiwan) according to the standard protocol provided by the company. 


\section{PCR-RFLP}

Amplification of the genomic DNA was by the following steps: denaturation at $94^{\circ} \mathrm{C}$ for 5 minutes, DNA amplification using 30 cycles. Each cycle contains the subsequent steps: denaturation at $94^{\circ} \mathrm{C}$ for the $30 \mathrm{~s}$, annealing for $30 \mathrm{~s}$, extension at $72^{\circ} \mathrm{C}$ for $40 \mathrm{~s}$, final elongation at $72^{\circ} \mathrm{C}$ for 7 minutes. The amplified DNA was electrophoresed on $2 \%$ agarose with ethidium bromide, (1X) TBE buffer at $100 \mathrm{~V}$ for 60 minutes. A $100 \mathrm{bp}$ ladder was used as a marker for estimating the size of the fragment.

The digestion with restriction enzyme was performed in $50 \mu 1$ containing $1 \mu 1$ of $A L U I$ restriction enzyme (Biolabs/England), $10 \mu \mathrm{l}$ of PCR product, $5 \mu \mathrm{l}$ of enzyme buffer $(1 \mathrm{x})$ and the volume was completed with nuclease deionized water and incubated at $37^{\circ} \mathrm{C}$ overnight. Products of PCR were digested fragments and detected by electrophoresis on $8 \%$ polyacrylamide gel.

Table 1: Sequences of primers used for PCR. .amplification of microRNAs genes

\begin{tabular}{|c|c|c|}
\hline Gene name & Primer sequence & Reference \\
\hline TSHR gene & F:5-CTAACCAGCAGAGGGAGCAC3 & \\
& R: $5^{-}$CCACTGCTTAAAGCCCAGAT3- & (Dechairo et al., 2005) \\
& (Yin et al., 2008) $^{-}$ & \\
\hline
\end{tabular}

\section{Statistical Analysis}

Analysis of the data was by using completely randomized design (CRD), Odd ratio and Pearson's goodness of fit chi-square test. The $\mathrm{p}$-value $\leq 0.05$

was regarded as significant. All analyses were performed using software of SPSS for Windows version 19.

\section{Results}

\section{DNA Extraction}

The result of DNA extraction was revealed in the figure (2).

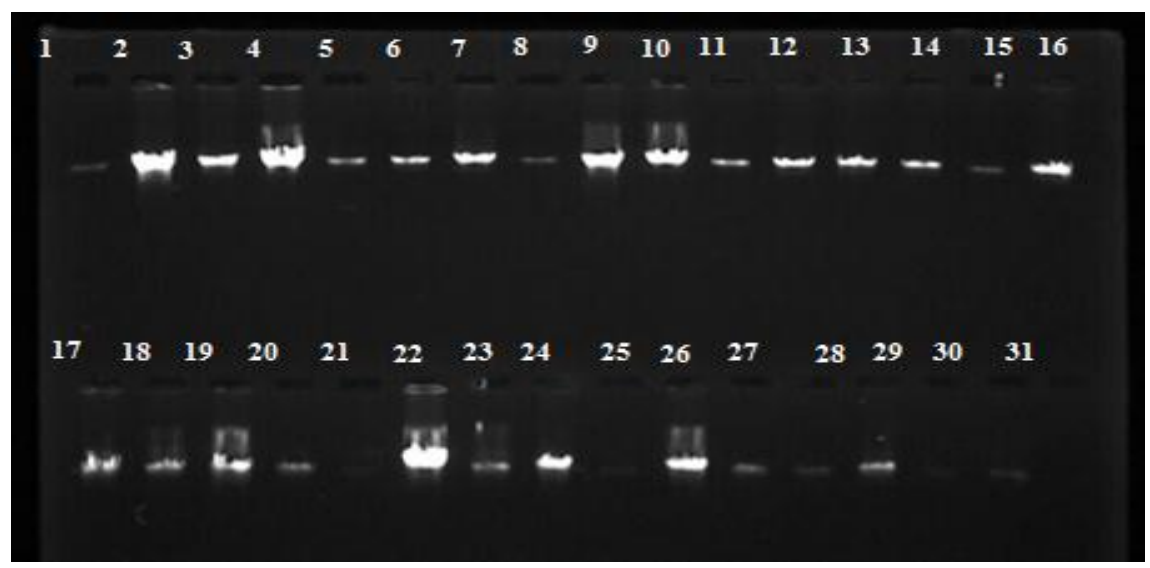

Figure (2): The electrophoresis pattern of genomic DNA extracted from WBC of hypothyroidism and healthy women, lane (1-16) for control and lane (17-31) for hypothyroidism women, 1\% agarose, 75 V, 20 Am for 1 hour. 
Determination of Annealing Temperature of TSHR Gene rs2268458 (Gradient PCR).

Annealing temperature had been determined by using temperature gradient $\left(66-69^{\circ} \mathrm{C}\right)$ and the optimum annealing temperature was $69^{\circ} \mathrm{C}$ as shown in Figure (3).

\section{Genotyping of TSHR rs 2268458}

The results of TSHR gene amplification showed that the amplification product was $162 \mathrm{bp}$ for patients and control as explained in the figure (4).

The product was digested with a restriction enzyme which cut the PCR- amplicon if C allele present resulting in 100 and $62 \mathrm{bp}$ fragments, by the other hand if T allele present the amplicon will not be cut and appear as intact 162 bp as shown in figure (5).

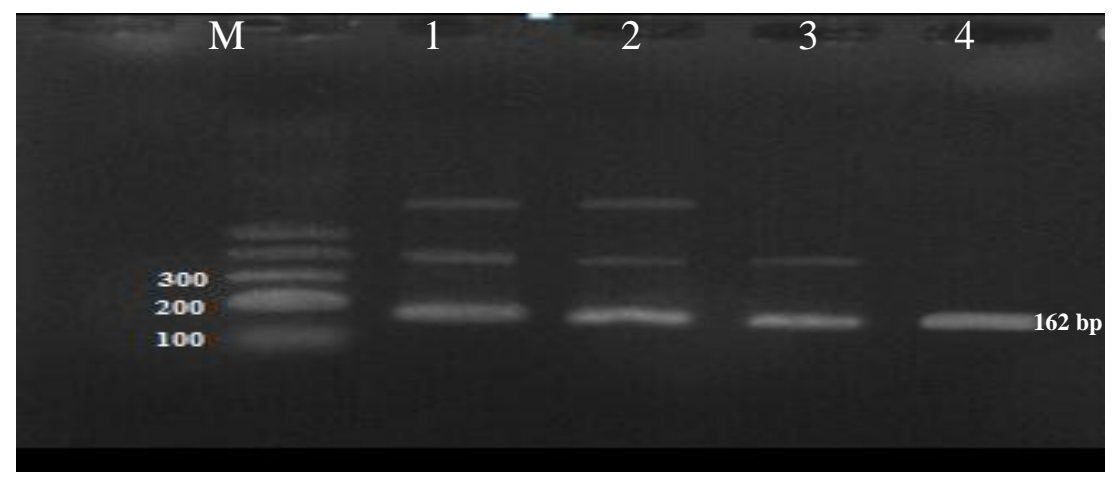

Figure (3): The electrophoresis pattern of gradient PCR product of TSHR gene at the different annealing temperature, the optimum annealing temperature was $69^{\circ} \mathrm{C}$, lane $\mathrm{M}$ : DNA ladder, Lane 1: $66^{\circ} \mathrm{C}$, Lane 2: $67^{\circ} \mathrm{C}$, Lane 3: $68^{\circ} \mathrm{C}$, Lane 4: $69^{\circ} \mathrm{C}$.

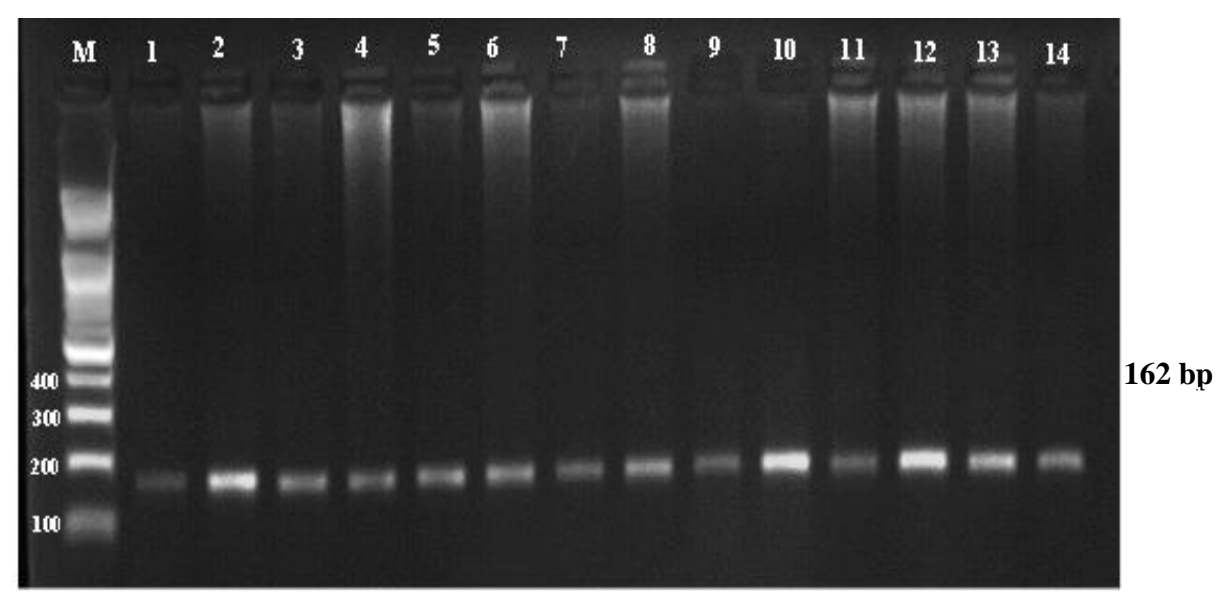

Figure (4): Electrophoresis pattern of PCR product for TSHR gene, amplification product was one band 162 bp, lane M: DNA ladder, lane (1-9): PCR product of patients, lane (10-14): PCR product of healthy subjects, $1 \%$ agarose, annealing $69^{\circ} \mathrm{C}$. 


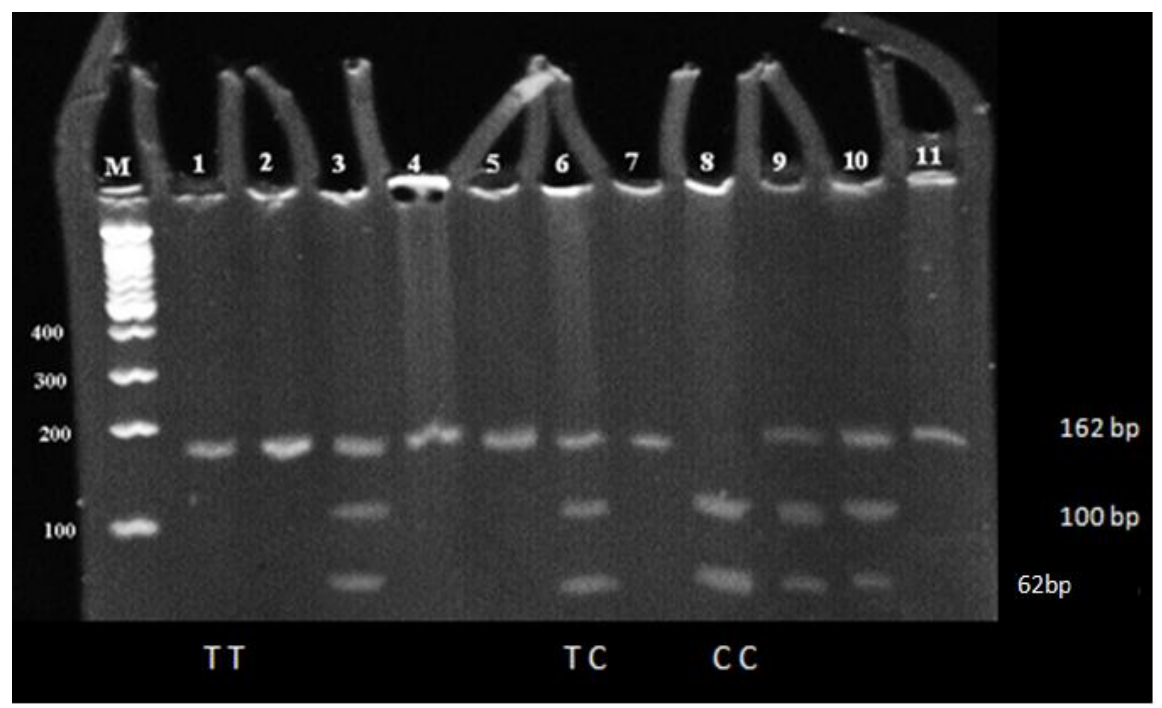

Figure (5): Electrophoresis pattern of PCR-RFLP for PCR product (162 bp) of TSHR gene polymorphism. Lane (14): control group. Lane (5-11): hypothyroidism patients, Lane $(3,6,9,10)$ : heterozygote (TC) genotype, Lane (1, 2, 4, 5, 7, 11): homozygote (TT) genotype, lane (8): homozygote (CC) genotype. Restricted fragments with restriction enzyme ALU1 were electrophoresed in $8 \%$ polyacrylamide gel, $0.5 \mathrm{X}$ TBE, 150V, 20mA for 3 hours. Samples of Analysis for Hardy-Weinberg equilibrium

The samples show there was no significant deviation from equilibrium of Hardy-Weinberg and this lead to assume that the samples represent the population and there is no significant error in the genotyping technique used in this study as shown in the table (2).

Table (2): Exact test for Hardy-Weinberg equilibrium.

\begin{tabular}{|c|c|c|c|c|c|c|}
\hline & \multicolumn{3}{|c|}{ Genotypes } & \multicolumn{2}{|c|}{ Alleles } & \multirow{2}{*}{ P-value* } \\
\hline & $\mathbf{T} / \mathbf{T}$ & $\mathrm{T} / \mathrm{C}$ & $\mathrm{C} / \mathrm{C}$ & $\mathbf{T}$ & C & \\
\hline All subjects & 73 & 20 & 1 & 166 & 22 & 1 \\
\hline Patients & 34 & 16 & 1 & 84 & 18 & 1 \\
\hline Control & 39 & 4 & 0 & 82 & 4 & 1 \\
\hline
\end{tabular}

* The two-tailed $\mathrm{P}$ value of Fisher's exact test

\section{Allele Frequency}

The result shows that $\mathrm{T}$ allele frequency in Iraqi population is $95 \%$ and $\mathrm{C}$ allele frequency is $5 \%$ this

frequency is compared to other population frequencies as shown in the figure (6). 

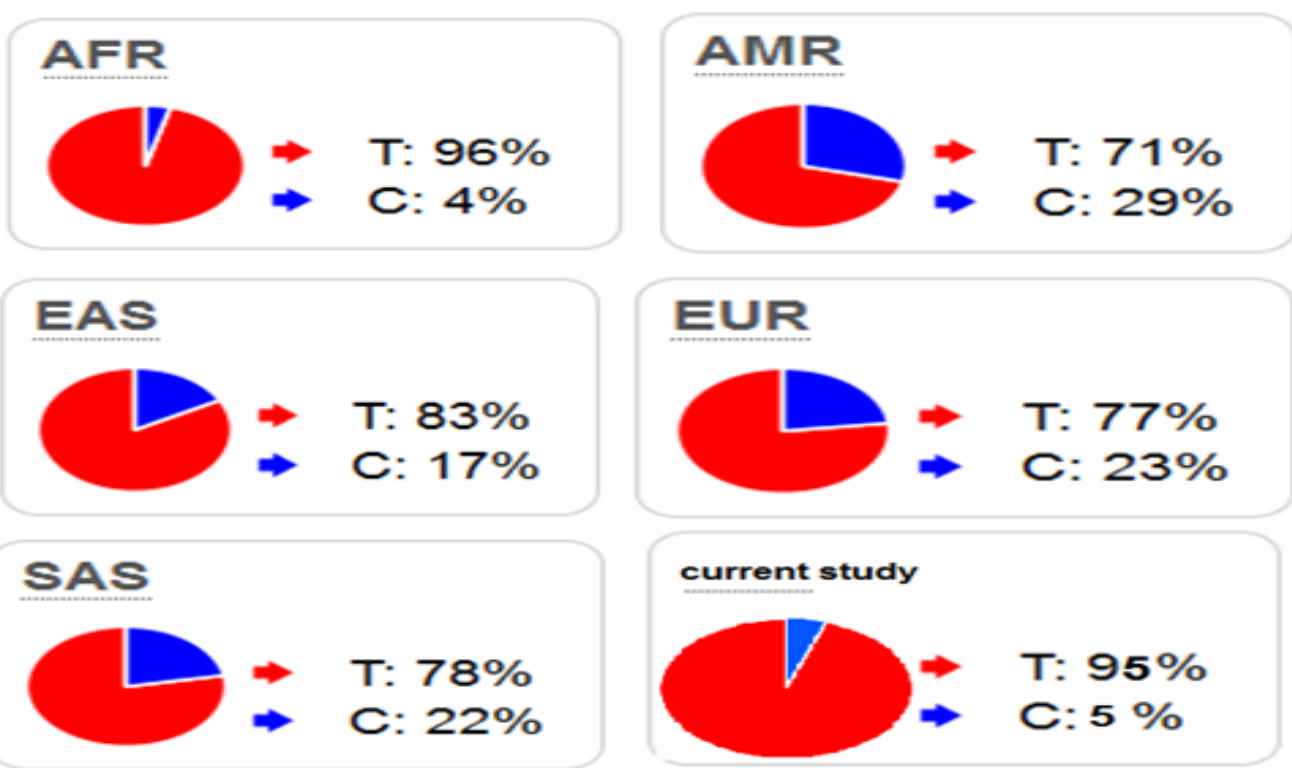

Figure (6): TSHR rs2268458 alleles frequencies in Babylon province population compared to several populations. The data and figures from other than studying population (current study) are adapted from 1000

Genomes Project Phase 3. (AFR= Africans; AMR= Americans; EAS= East Asians; EUR= Europeans; SAS=South Asians).

\section{Allelic Association of TSHR gene rs2268458 in Hypothyroidism}

The result of allelic association showed that the allele $\mathrm{T}$ was less frequent in hypothyroidism patients 0.82 when compared to control group $0.95(\mathrm{OR}=0.228, \mathrm{CI}=0.074-0.701)$ while the allele $\mathrm{C}$ was more frequent in hypothyroidism patients 0.18 when compared to control group 0.05 ( $\mathrm{OR}=4.393, \mathrm{CI}=1.42-13.53$ ), by the other words allele $\mathrm{C}$ has a significant association with hypothyroidism disease which mean that the individual who carries $\mathrm{C}$ allele was susceptible to hypothyroidism by $(\mathrm{OR}=4.393)$ and $(\mathrm{CI}=1.42-13.53)$ as shown in table (3).

Table (3): Genotype of TSHR gene rs2268458 polymorphism with the Allelic association.

\begin{tabular}{|c|c|c|c|c|c|c|}
\hline & \multicolumn{2}{|c|}{ Patients } & \multicolumn{2}{|c|}{ Control } & \multirow{2}{*}{ OR $(95 \%$ CI $)$} & \multirow{2}{*}{$\begin{array}{c}\text { P- } \\
\text { value* }\end{array}$} \\
\hline Allele & Count & Proportion & Count & Proportion & & \\
\hline $\mathrm{T}$ & 84 & 0.82 & 82 & 0.95 & $0.228(0.074-0.701)$ & \multirow[t]{2}{*}{0.0057} \\
\hline $\mathrm{C}$ & 18 & 0.18 & 4 & 0.05 & $4.393(1.42-13.53)$ & \\
\hline
\end{tabular}

* Pearson's goodness-of-fit chi-square.

\section{Genotypes Association of rs 2268458 with Hypothyroidism}

Allele $\mathrm{C}$ shows its pathological effect on different inheritance patterns in dominant, codominant and overdominant but its largest effect is in the dominant model of inheritance $(\mathrm{P}=0.006, \mathrm{OR}=4.87, \mathrm{CI}=1.49-15.90)$ and from this, it can be assumed that allele $\mathrm{C}$ is a pathological allele and inherited in a dominant model. The association of genotype under different models of inheritance are detected in the Table (4). 
Table (4): Genotypes association of rs $\mathbf{2 2 6 8 4 5 8}$ with hypothyroidism under different patterns of inheritan

\begin{tabular}{|c|c|c|c|c|c|}
\hline & Genotype & Patients & Control & OR $(95 \% \mathrm{CI})$ & P-value* \\
\hline \multirow{3}{*}{ Codominant } & $\mathrm{T} / \mathrm{T}$ & $34(66.7 \%)$ & $39(90.7 \%)$ & 1.00 & \multirow{3}{*}{0.007} \\
\hline & $\mathrm{T} / \mathrm{C}$ & $16(31.4 \%)$ & $4(9.3 \%)$ & $4.59(1.40-15.06)$ & \\
\hline & $\mathrm{C} / \mathrm{C}$ & $1(2 \%)$ & $0(0 \%)$ & $3.435(0.135-87.094)$ & \\
\hline \multirow{2}{*}{ Dominant } & $\mathrm{T} / \mathrm{T}$ & $34(66.7 \%)$ & $39(90.7 \%)$ & 1.00 & \multirow{2}{*}{0.006} \\
\hline & $\mathrm{T} / \mathrm{C}-\mathrm{C} / \mathrm{C}$ & $17(33.3 \%)$ & $4(9.3 \%)$ & $4.87(1.49-15.90)$ & \\
\hline \multirow{2}{*}{ Recessive } & $\mathrm{T} / \mathrm{T}-\mathrm{T} / \mathrm{C}$ & $50(98 \%)$ & $43(100 \%)$ & 1.00 & \multirow{2}{*}{1.00} \\
\hline & $\mathrm{C} / \mathrm{C}$ & $1(2 \%)$ & $0(0 \%)$ & $2.58(0.10-65.08)$ & \\
\hline \multirow{2}{*}{ Overdominant } & $\mathrm{T} / \mathrm{T}-\mathrm{C} / \mathrm{C}$ & $35(68.6 \%)$ & $39(90.7 \%)$ & 1.00 & \multirow{2}{*}{0.011} \\
\hline & $\mathrm{T} / \mathrm{C}$ & $16(31.4 \%)$ & $4(9.3 \%)$ & $4.46(1.36-14.61)$ & \\
\hline
\end{tabular}

\section{The Concentration of Physio-Biochemical Parameters According to TSHR rs2268458 Genotype}

The result of the study showed that there was no association between TSHR rs2268458 and thyroid function tests (TSH, $\mathrm{ft} 3$, and $\mathrm{ft} 4$ ) but there was a significant difference between the genotypes of this SNP and each of the following: BMI, CT, and CYP1A1, where TC and CC genotypes were associated with high BMI, while TC genotype was associated with high CT and CYP4501A1 levels, as shown in table (5).

Table (5): The concentration of physio-biochemical parameters according to TSHR rs2268458 genotype.

\begin{tabular}{|c|c|c|c|c|}
\hline \multirow[b]{2}{*}{$\begin{array}{c}\text { Variable } \\
(\text { Mean } \pm \text { S.E })\end{array}$} & \multicolumn{3}{|c|}{ Patients } & \multirow[b]{2}{*}{ LSD } \\
\hline & $\begin{array}{c}\text { TT } \\
\mathrm{N}=34\end{array}$ & $\begin{array}{c}\text { TC } \\
\mathrm{N}=16\end{array}$ & $\begin{array}{c}\mathrm{CC} \\
\mathrm{N}=1\end{array}$ & \\
\hline BMI $\left(\mathrm{Kg} / \mathrm{m}^{2}\right)$ & $29.16 \pm 5.27$ & $32.98 \pm 4.26$ & $38.28 \pm 0.0$ & 2.965 \\
\hline TSH $(\mu \mathrm{Iu} / \mathrm{ml})$ & $14.37 \pm 4.87$ & $14.38 \pm 4.92$ & $5.51 \pm 0.0$ & 14.816 \\
\hline $\mathrm{fT}_{3}(\mathrm{Pg} / \mathrm{ml})$ & $1.58 \pm 0.89$ & $1.58 \pm 0.88$ & $1.13 \pm 0.0$ & 0.528 \\
\hline $\mathrm{fT}_{4}(\mathrm{ng} / \mathrm{dL})$ & $0.61 \pm 0.29$ & $0.55 \pm 0.22$ & $0.49 \pm 0.0$ & 1.164 \\
\hline OPN (ng/ml) & $3.39 \pm 1.66$ & $4.25 \pm 1.55$ & $5.76 \pm 0.0$ & 3.967 \\
\hline CT $(\mathrm{Pg} / \mathrm{ml})$ & $51.99 \pm 4.14$ & $59.19 \pm 14.78$ & $49.84 \pm 0.0$ & 5.328 \\
\hline CYP (ng/ml) & $7.42 \pm 0.84$ & $7.91 \pm 1.02$ & $5.03 \pm 0.0$ & 0.336 \\
\hline $\mathrm{Ca}(\mathrm{mg} / \mathrm{dL})$ & $8.22 \pm 1.17$ & $8.11 \pm 1.24$ & $8.03 \pm 0.0$ & 0.711 \\
\hline$P(\mathrm{mg} / \mathrm{dL})$ & $4.39 \pm 2.35$ & $3.95 \pm 0.78$ & $4.89 \pm 0.0$ & 1.187 \\
\hline
\end{tabular}

\section{CRD, $\mathbf{P} \leq \mathbf{0 . 0 5}$}

\section{Correlation between rs2268458 genotypes of TSHR gene and Physio- Biochemical parameters}

The results of the study show that in TT genotype there was a significant positive correlation between OPN and each of the following: fT4 level $\left(\mathrm{R}^{2}=0.127, \mathrm{p}=0.038\right)$ and CYP1A1 level $\left(\mathrm{R}^{2}=0.187, \mathrm{p}=0.01\right.$ as shown in figure (7). 

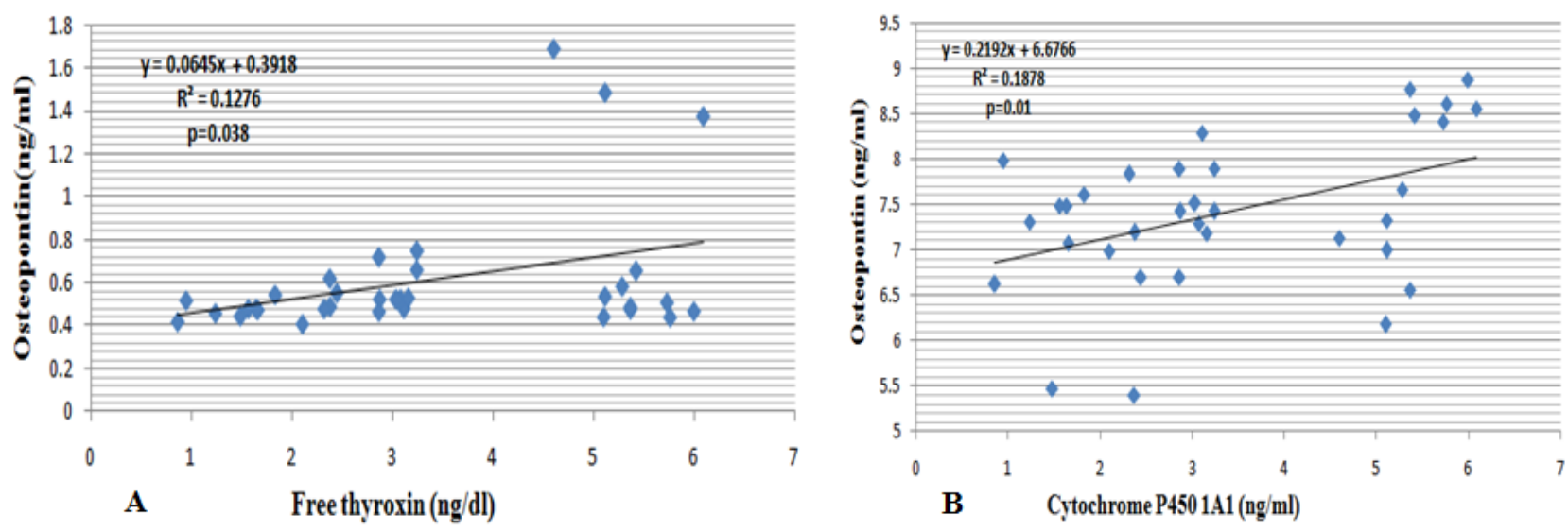

Figure (7): Linear regression analysis revealed positive correlation between osteopontin and free thyroxin (A) and cytochrome P450 1A1 (B) in TT genotype.

In addition, there was a significant positive correlation between OPN and CT mean levels in TC genotype $\left(\mathrm{R}^{2}\right.$ $=0.251, \mathrm{p}=0.048$ as shown in the figure $(8)$.

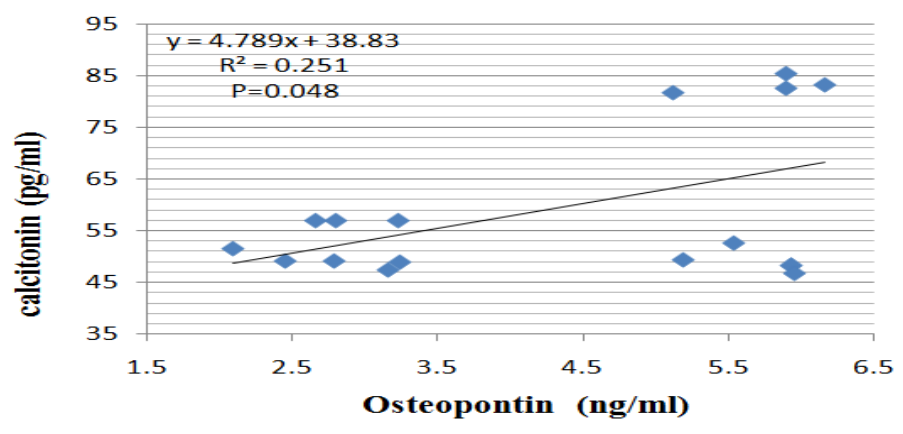

Figure (8): Linear regression analysis revealed a positive correlation between calcitonin and osteopontin in TC genotype. 


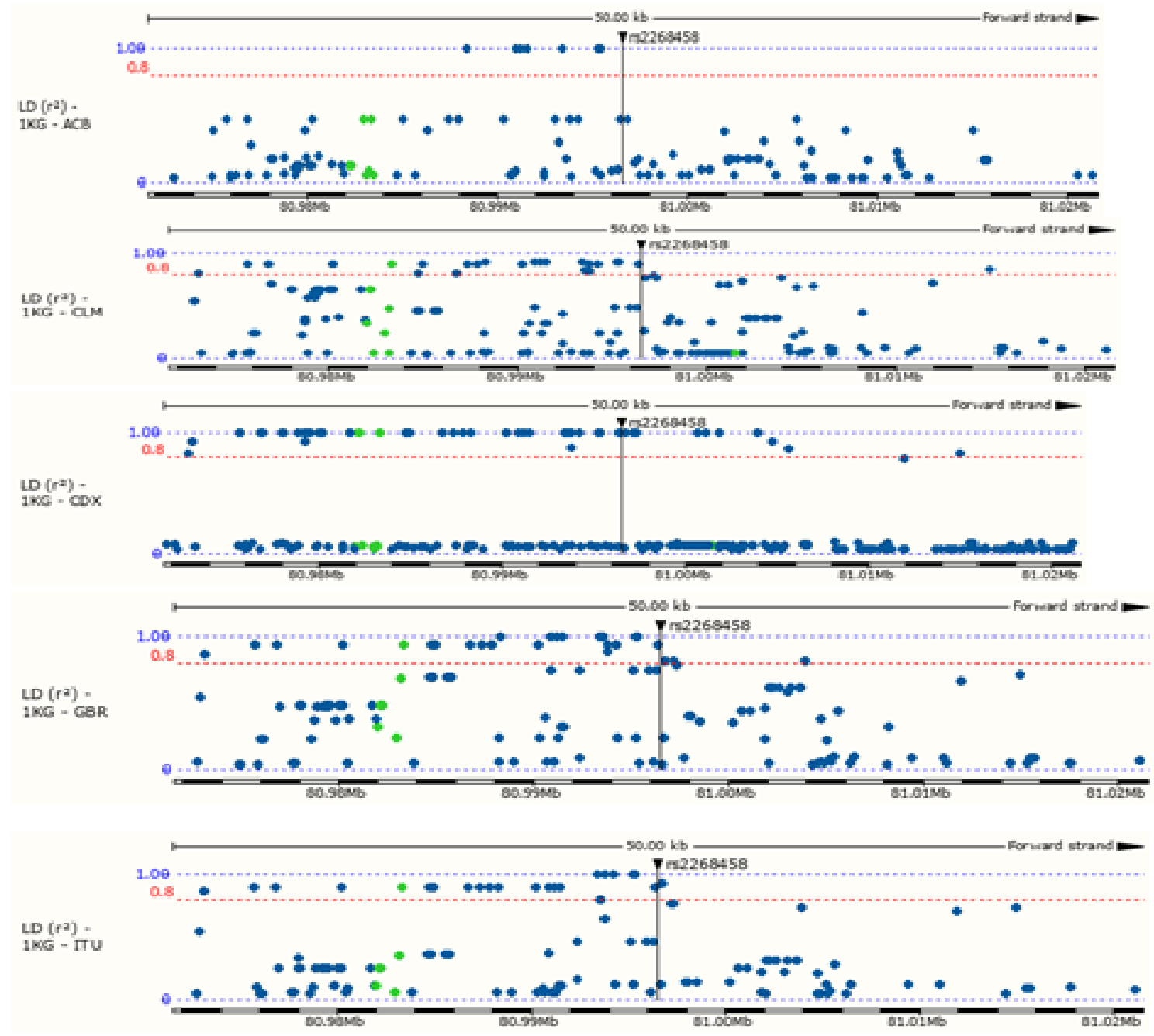

Figure (9): Manhattan plots of linkage disequilibrium (LD) in different population estimated by $\mathbf{r}^{2}$ for variants linked to rs2268458 variant (ACB: African Caribbean in Barbados, CLM: Colobianin Medellin, Colombia, CDX: Chinese Dai in Xishuan-gbanna, GBR: British in England and Scotland, ITU: Indian Telugu in the UK) (Ensembl release 91 - December 2017 (C) EMBL-EBI).

\section{Discussion}

Genetics had an important role in both determinations of TSH and thyroid hormone concentrations and vulnerability to thyroid disease. Heritability studies have referred that up to $67 \%$ of TSH and thyroid hormone concentrations in circulation are genetically settled and TSH receptor gene is one of the candidate genes which contribute in the variability of thyroid hormone concentrations [9].TSH regulates the secretion of thyroid gland and growth through binding with its receptors (TSHR) [6] which are found not only in thyroid follicular cells, besides finding in osteoclasts and osteoblasts and several studies regarded that TSH as a negative regulator of bone turnover [10], [11]. According to the previous study, genetic variants in the TSHR gene was described to be associated with the risk of thyroid diseases[7].

The TSHR rs2268458 was confirmed its association with Graves' Disease (GD) in

Caucasians[8]. The current study has been discussed whether or not the association of TSHR rs2268458 with thyroid function tests (FT3, FT4, and TSH) as well as other physio-biochemical parameters in Iraqi hypothyroidism women in Babylon province. Many studies have investigated the role of mutations and the polymorphism in TSHR gene in the development of different thyroid diseases [12], [13], [8], [14].

The result of this study show that allele $\mathrm{C}$ has a pathological effect on Iraqi hypothyroidism women and its largest effect in the dominant model, so TC and CC genotypes are associated with hypothyroidism disease and this 
result disagrees with [15]who reported that TSHR rs2268458 polymorphisms were not associated with hypothyroidism disease in Lebanon population. This outcome indicates the supportive of genetic factors finding in this region that may be in linkage disequilibrium with the inheritance of different TSHR polymorphisms [16], so the difference between results can be explained by the differences in linkage disequilibrium in this polymorphism rs2268458 in different populations as shown in figure (9), where the figure demonstrates that this region of rs2268458 is highly polymorphic from population to population.

The result of this study showed that there was no association between rs2268458 polymorphism and thyroid function tests (TSH, fT3 and fT4) which may be due to that allele C may has Quantitative Trait Loci (QTL) which affect disease in quantization manner and need for QTL of another allele which may be different from population to another population as elucidated in figure (9) or may be due to low statistical power of our small sample size. These results agree with [17] who found a significant difference in the allelic frequency of the P52T polymorphism and did not discover any association between genotypes and serum TSH levels. Polymorphism does not essentially have to play a functional role [18]. In TSHR gene, many polymorphisms have been described and associated with a slight increase in TSH level [19] while other polymorphisms and mutations in other genes, such as PAX-8, FOXE1, and thyroid transcription factors TITF-1 could inhibit the expression of TSHR [20].

The result of the current study revealed that TC and CC genotypes were associated with high BMI, which may be due to allele $\mathrm{C}$ which has a significant association with hypothyroidism in this study and may act to disrupt the balance between energy expenditure and energy intake that result in obesity. In this study TC genotype was associated with high CT and CYP4501A1 levels which may be due to the changes in thyroid function in hypothyroidism patients can affect the osteomineral metabolism causing changes in the dynamics of calcitonin secretion [21] and there was another explanation that in this study allele $\mathrm{C}$ which has a significant association with hypothyroidism may be effective on the target genes for calcitonin and CYP4501A1 expression. In the previous study, total thyroidectomy could cause a significant increase in BMI and a significant decrease in thyroid hormones, OPN and calcium levels in Iraqi hypothyroid women [22].

The correlation study in TT genotype record a significant positive correlation between OPN and each fT4 and CYP4501A1 levels and this result agreed with [23] who found a positive correlation between osteopontin and thyroxin hormone and several studies reported that OPN was decreased in hypothyroidism [23], [24] which may be resulting from some processes of cell going on in the thyroid gland which probably decrease OPN receptor coexpression [23]. The significant positive correlation between OPN and CYP450 1A1 levels in this study accordance with [23], [25] who reported that CYP450 and OPN were decreased in hypothyroidism patients and this decreasing in CYP450 level may be because the low level of thyroid hormone in hypothyroidism patients which is responsible for regulation of expression of CYP through its control on levels of cellular CYP reductase, which had the ability to inactivate CYPs [26].

To our knowledge, this is the first study showing an association of TSHR gene rs2268458 polymorphism with hypothyroidism in Iraqi women. Our results suggest that the individual who carries $\mathrm{C}$ allele was susceptible to hypothyroidism by $\mathrm{OR}=4.393 \mathrm{CI}=1.42-13.53$. Also, TC and $\mathrm{CC}$ genotypes were associated with high BMI while TC genotype was associated with high calcitonin and CYP1A1 levels.

\section{CONFLICT OF INTERESTS}

\section{There are no conflicts of interest.}

\section{References}

[1] H. J. Baskin, and R.H. Cobin, D. S., "Duick. American Association of Clinical Endocrinologists medical guidelines for clinical practice for the evaluation and treatment of hyperthyroidism and hypothyroidism". Endocr.Pract., 8: 457-469. 2002.

[2] M.Louwerens, B.C. Appelhof, and H.Verloop, "Fatigue and fatigue-related symptoms in patients treated for different causes of hypothyroidism”. Eur J Endocrinol, 167: 809-815. 2012.

[3] J.Zhang, and M. A. Lazar, "The mechanism of action of thyroid hormones". Annu Rev Physiol, 62: 439-466. 2000.

[4] Y. Wu, and R. J. Koenig,. "Gene regulation by thyroid hormone". Trends Endocrinol. Metab., 11:207211.2000.

[5] Y.J.Park, E. K.Lee, Y.K. Lee, D.J.Park, H.C.Jang, and D. Moore, “Opposing Regulation of Cytochrome P450 Expression by CAR and PXR in Hypothyroid Mice”. Toxicol. Appl. Pharmacol., 263(2): 131-137.2012. 
[6] F.Lizcano, and J.S. Rodriguez, "Thyroid hormone therapy modulates hypothalamo-pituitary-adrenal axis". $J$ Endocr, 58: 137-142. 2011.

[7] T. D. Davies, X. Yin, and R.Latif, "The Genetics of the Thyroid Stimulating Hormone Receptor: History and Relevance". Thyroid, 20 (7).2010.

[8] X.Yin, R.Latif, R.Bahn, Y. Tomer, and T.F. Davies," Influence of the TSH receptor gene on susceptibility to Graves' disease and Graves' ophthalmopathy". Thyroid, 18: 1201-1206.2008.

[9] V. Panicker,"Genetics of Thyroid Function and Disease". Clinical Biochemists, 32 (4):165-175. 2011.

[10] J. Nicholls, M.Brassil, G. Williams, and J.Bassett, "The skeletal consequences of thyrotoxicosis". J. Endocrinol., 213: 209-221.2012.

[11] J.Gorka, R. Taylor-Gjevre, and T. Arnason, Metabolic and clinical consequences grades of hypothyroidism and controls. J.Clin. Endocrinol. Metab., 82:771-777. 2013.

[12] B.M.Dechairo, D.Zabaneh, and J. Collins, “Association of the TSHR gene with Graves' disease: the first disease specific locus”. Eur. J. Hum. Genet., 13: 1223-1230.2005.

[13] L.Arnaud-Lopez, G.Usala, and G.Ceresini, "Phosphodiesterase 8B gene variants are associated with serum TSH levels and thyroid function”. Am J. Hum. Genet., 82: 1270-1280. (2008).

[14] M. Cerbone, P. Agretti, and G. De Marco, "Nonautoimmune subclinical hypothyroidism due to a mutation in TSH receptor: report on two brothers". Ital. J. Pediatr., 39: 5. (2013).

[15] S. I. Al-Azzam, K. H. Alzoubi, O. Khabour, and O. Al-Azzeh,“ The associations of polymorphisms of TSH receptor and thyroid hormone receptor genes with L-thyroxine treatment in hypothyroid patients". Hormones, 13(3): 389-397. 2014.

[16] S. Ho, S.Goh, and D. Khoo, Association of Graves' "Disease with Intragenic Polymorphism of the Thyrotropin Receptor Gene in a Cohort of Singapore Patients of Multi-Ethnic Origins". Thyroid, 13(6): 523-528. (2004).

[17] F .Teofoli, M. Camilot, and L. Tatò," Lack of association between thyrotropin receptor gene polymorphisms and subclinical hypothyroidism in children”. J. Endocrinol.,30 (2):163-166.2007.

[18] G. De Marco, P. Agretti, M.Camilot, F.Teofoli, L.Tato, P.Vitti, A.Pinchera, and M.Tonacchera, "Functional studies of new TSH receptor (TSHr) mutations identified in patients affected by hypothyroidism or isolated hyperthyrotropinaemia". Clin. Endocrinol., 70:335-338.2009.

[19] A. Rapa, A.Monzani, S.Moia, D.Vivenza, S.Bellone, and A. Petri, Subclinical Hypothyroidism in Children and Adolescents: A Wide Range of Clinical, Biochemical, and Genetic Factors Involved. J. Clin. Endocrinol. Metab., 94: 2414-2420. 2009.

[20] K.Nagasaki, S.Narumi, T.Asami, T. Kikuchi, T. Hasegawa, and M.Uchiyama, "Mutation of a gene for thyroid transcription factor-1 (TITF1) in a patient with clinical features of resistance to thyrotropin". Endocr. J., 55:875-878. 2008

[21] F. J.Stamato, E.C. Amarante, and R.P. Furlanetto, Effect of combined treatment with calcitonin on bone densitometry of patients with treated hypothyroidism. Rev. Ass. Med. Brasil., 46 (2): 177-181.2000.

[22] B. I.Hussain, H. J. AL-Harbi, and M. A. MaysaaAdil Hadi, "Impact of Thyroidectomy in BMI and Some Biochemical Markers Related with Bone Turnover in Hypothyroidism Women". Research Journal of Pharmacy and Technology,11(6-7).(accepted for publication). 2017

[23] S.Reza, A.Shaukat, T.M. Arain, Q. S. Riaz, and M.Mahmud, "Expression of Osteopontin in Patients with Thyroid Dysfunction". PLOS ONE, 8 (2): e56533.2013.

[24] M.A.Alwakeel, M.Hend, and S.M. Abd El Hamid, "Osteopontin as a new biomarker for diagnosis patients with thyroid dysfunction". AAMJ, 10: 3.2012.

[25] M.Haas, J.Kletzmayer, T.Staudinger, G.Bohmig, G. Mayer, Z.Leko-Mohr, and W.Druml,"Hypothyroidism as a cause of tacrolimus intoxication and acute renal failure: a case report". Wien Klin Wochenschr.,112: 939-941. 2000. 
[26] K.A. O'Leary, H.C Li, P.A. Ram, P. Mc Quiddy, D. J. Waxman, and C.B. Kasper, "Thyroid regulation of NADPH: cytochrome P450oxidoreductase: identification of a thyroid-responsive element in the 5'-flank of the oxidoreductase gene".Mol. Pharmacol., 52 (1) :46-53. 1997.

الخلاصة:

الهُف من الدراسة: التقييم العلاقة بين تعدد الاثكال في الجين TSHR rs2268458 وبعض المعايير الفسلجية البايوكيمبائية في النساء اللواتي يعانن من نقص الافراز الدرقي. طرق العمل: تضمنت هذه الدراسة اه امر أة تعاني من نقص الافراز الدرقي ورّأ امرأة صحيحة كمجموعة سيطرة. تضمنت الفحوصات الفسلجية والبايوكيميائية كل من مؤشر كتلة الجسم، السايتوكروم، الكالسيوم والفسفور ـ شملت الفحوصات الهرمونية كل من الاوستيوبونتين ،الهرمون المحفز للارقية والهرمون الدرقي الحر وهرمون الكالسيتونين. نم اجراء التتمبط للجين TSHR

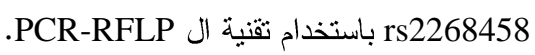
النتائج: يرتبط تعدد الاشكال بال TSHR rs2268458 مع مرض نقص الافراز الدرقي في النساء العر اقيات ويعد الاليل C عامل

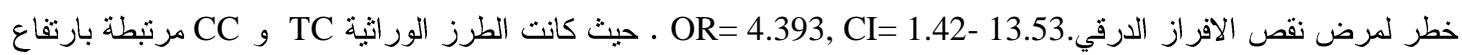
مؤشر كتلة الجسم بينما ارتبط الطر از الور اثي مCيع المستويات العالية من السايتوكروم CYP4501A1 و الكالسيتو نين. الاستتتاج: ان تعدد الاشكال بالجين TSHR rs2268458 له علاقة بمرض نقص الافراز الدرقي في النساء العر اقيات وان الاليل يمكن ان يكون عامل خطر لبعض الاختلالات الهرمونية والمعايير الكيميائية الفسلجية في مريضات نقص الافراز الدرقي.

$$
\text { الكلمات الدالة: جين TSHR، rs2268458, نقص الافراز الدرقي, العراق. }
$$

